\title{
CREATIVITY AND INNOVATION AS DEFINED BY WORKERS
}

\author{
Sônia Maria Guedes Gondim* \\ sggondim@gmail.com \\ Elisabeth Loiola* \\ beteloiola@oi.com.br \\ Franciane Andrade de Morais* \\ francianeandrade@hotmail.com \\ Silvia Cristina da Costa Dutra** \\ silviacristina.dacosta@ehu.es \\ Dario Paéz Rovira** \\ dario.paez@ehu.es
}

Marta Rodrígues**

marta.rodriguez@ehu.es

Daniela Cristina Ribeiro de Lima*

danielacrl27@gmail.com

Luciana Mourão***

mourao.luciana@gmail.com

*Universidade Federal da Bahia - Salvador, BA / Brasil

**Universidad del País Vasco, San Sebastian / Espanha

***Universidade Salgado de Oliveira, Rio de Janeiro, RJ

http://dx.doi.org/10.1590/1413-2311.0162015.55629

Recebido em 16/03/2015

Aprovado em 21/12/2015

Disponibilizado em 31/12/2015

Avaliado pelo sistema "double blind review"

Revista Eletrônica de Administração

Editor: Luís Felipe Nascimento

ISSN 1413-2311 (versão "on line")

Editada pela Escola de Administração da Universidade Federal do Rio Grande do Sul.

Periodicidade: Quadrimestral

Sistema requerido: Adobe Acrobat Reader

\begin{abstract}
Creativity and innovation are now required given the new configurations in work processes, in organizational formats, in physical and intangible technologies, as well as in products and markets. In parallel with the growing centrality and interest in the phenomena of creativity and innovation, a broadening of its concepts is observed. The inflation and trivialization of uses tend to make them self-explanatory and not very enlightening regarding situations to which they apply and the associated effects. The lack of conceptual clarity thus contributes both to undermining policies to promote creativity and innovation in organizations, as well as to hinder the employees' adherence to such policies. The study aimed to characterize the key elements of workers' informal definitions of creativity and innovation, and identify their alignment with definitions and theoretical perspectives. The study included 231 workers from
\end{abstract}


Portuguese-, Spanish-, and Basque-speaking countries, aged 22-75 years. The qualitative data analysis software ATLAS.ti 7 was used for coding and categorization. One point of convergence with the specialized literature was that creativity and innovation strongly associated with novelty in the development of an idea / product / process / service. Creativity, however, is defined more in terms of dispositional factors rather than contextual and situational factors, diverging from current theoretical perspectives. Planning as a key aspect for organizational innovation development is practically absent from the workers' definitions. It discusses some impacts of these settings for organizational management practices.

Keywords: Creativity; Organizational innovation; Management

\section{CRIATIVIDADE E INOVAÇÃO DEFINIDAS POR TRABALHADORES}

\section{RESUMO}

A criatividade e inovação passam a ser requeridas em virtude das novas configurações nos processos de trabalho, nos formatos organizacionais, nas tecnologias físicas e intangíveis, e ainda nos produtos e mercados. Em paralelo à crescente centralidade e interesse pelos fenômenos de criatividade e de inovação, observa-se o alargamento de seus conceitos. A inflação e banalização de usos tendem a torná-los autoexplicáveis e pouco elucidativos de situações a que se aplicam e dos efeitos associados. A ausência de clareza conceitual contribui, assim, tanto para fragilizar as políticas de promoção da criatividade e inovação nas organizações, quanto para dificultar a adesão dos trabalhadores a tais políticas. O estudo objetivou caracterizar os elementos-chave das definições livres de criatividade e inovação de trabalhadores e a identificação de seu alinhamento a definições e perspectivas teóricas presentes na literatura sobre o tema. Participaram do estudo 231 trabalhadores de países de língua portuguesa, espanhola e euskera, com idade entre 22 a 75 anos de idade. Fez-se uso do software de análise de dados qualitativos Atlas TI 7 versão 1.8 para codificação e categorização. Um ponto de convergência com a literatura especializada foi que a criatividade e inovação apresentaram-se fortemente associadas à novidade no desenvolvimento de uma ideia/produto/processo/serviço. A criatividade, no entanto, é definida mais em termos de fatores disposicionais que de fatores contextuais e situacionais, distanciando-se das perspectivas teóricas atuais. O planejamento como um aspecto-chave para o desenvolvimento da inovação organizacional está praticamente ausente das definições dos trabalhadores. Analisam-se os impactos dessas definições para as práticas de gestão organizacional.

Palavras-chave: Criatividade; Inovação organizacional; Gestão

\section{CREATIVIDAD E INNOVACIÓN DEFINIDAS POR LOS TRABAJADORES RESUMEN}

Tanto la creatividad como la innovación son necesarias si tenemos en cuenta las nuevas configuraciones en los procesos del trabajo, en los formatos organizacionales, en las tecnologías físicas e intangibles, así como en los productos y mercados. Al tiempo que se produce una mayor centralidad e interés en el fenómeno de la creatividad y la innovación, asistimos a un desarrollo de sus conceptos asociados. La inflación y trivialización en sus usos tienden a hacerlos autoexplicativos y sin capacidad para ilustrarnos sobre aquellas situaciones a las que hacen referencia y sus efectos asociados. La falta de claridad conceptual contribuye a socavar políticas que promuevan la creatividad e innovación en las organizaciones y dificultan la implicación de los trabajadores en dichas politicas. El objetivo de este estudio fue caracterizar los elementos principales que forman parte de las definiciones informales de

REAd | Porto Alegre - Edição 82 - N 3 - setembro/dezembro 2015 - p. 549-575 


\section{Sônia Maria Guedes Gondim, Elisabeth Loiola, Franciane Andrade de Morais \& Silvia} Cristina da Costa Dutra

creatividad dadas por los trabajadores e identificar su pertenencia a distintas definiciones y perspectivas teóricas existentes en la literatura sobre el tema. En este estudio participaron 231 trabajadores de lengua portuguesa, española y vasca, entre 22 y 75 años de edad. Para la categorización y codificación de los datos se utilizó el atlas Ti 7, versión 1.8. Una característica convergente con la bibliografía especializada fue que la creatividad y la innovación se encontraban fuertemente asociadas a novedad en el desarrollo de una idea/producto/proceso/servicio. La creatividad, sin embargo, era definida más en términos de factores disposicionales que de factores contextuales y situacionales, distanciándose de las perspectivas teóricas actuales. La planificación como aspecto clave en el desarrollo de la inovación organizacional está prácticamente ausente en las definiciones dadas por los trabajadores. Se analizan los efectos de estas definiciones en las prácticas de gestión organizacional.

Palabras clave: Creatividad; Innovación organizacional; Gestión

\section{INTRODUÇÃO}

Recent meta-analysis studies have pointed to the importance of dispositional, group, and contextual factors in explaining organizational creativity and innovation (e.g., DA COSTA et al., 2014; EKVALL, 1996; HAMMOND; GUY, G.; HOOTEGEM,, 2011; HÜLSHEGER; ANDERSON; SALGADO, 2009; HUNTER; BEDELL; MUMFORD, 2007; MA, 2009).

Interest in the subject is in tune with complex contemporary capitalism, strongly guided by the technological paradigm and by economic conditions that impose greater organizational competitiveness (RODRIGUES; VELOSO, 2013). Creativity and innovation are now required given the new configurations in work processes, in organizational formats, in physical and intangible technologies, as well as in products and markets (LUBART, 2007; ZHOU and KOEVER, 2014). In parallel with the growing centrality and interest in the phenomena of creativity and innovation, a broadening of its concepts is observed (e.g., HALL, 2010; ISAR; ANHEIER, 2010). The inflation and trivialization of uses tend to make them self-explanatory and not very enlightening regarding situations to which they apply and the associated effects. The lack of conceptual clarity (BECKER et al., 2001) thus contributes both to undermining policies to promote creativity and innovation in organizations, as well as to hinder the employees' adherence to such policies.

Although in recent years creativity and innovation are presented as related and strongly associated concepts (ISAR; ANHEIER, 2010), strictly speaking, they have distinct theoretical traditions. Creativity is rooted in psychological approaches (e.g., AMABILE, 1996; BODEN, 1994; CSIKSZENTMIHALYI，1996; ROAZZI; SOUZA， 1997; OSTROWER， 2009), whereas innovation is grounded in aspects of economic theory, technology, and 


\section{CREATIVITY AND INNOVATION AS DEFINED BY WORKERS}

entrepreneurship (MAZZONI; STRACHMAN, 2012; MCMULLAN; KENWORTHY, 2015; SCHUMPETER, 1961, 1982). Historically, creativity studies focus more on cognitive and psychosocial processes for generating new ideas or products, while those on innovation focus primarily on contextual processes, for deployment and transfer / dissemination of tangible and intangible innovative technologies (HAMMOND et al., 2011; HÜLSHEGER et al., 2009).

Although the interrelation between the two concepts in the organizational area is one mark, it can be said, roughly, that creativity has as its object the process of original design, while innovation involves the result or product that originates from this process (MARKS and HUZZARD, 2008). However, technology transfer can be uncoupled from the original creative process, as in the example of an organization that adopts an innovative technology that was designed strictly by another.

It is recognized that designating clearly delimited concepts of innovation and creativity is important for mitigating problems and supporting advances in both fields of research, ensuring greater effectiveness in organizational intervention proposals. This delimitation is more challenging in the field of organizations, in which the development of creativity holds innovation as its ultimate goal. In this field, understanding group and contextual aspects that favor creativity can help enhance organizational innovation.

Intending to contribute to the debate surrounding the concept and the definitions of creativity and innovation, the study presented in this article aimed to analyze definitions of these terms by workers who responded to a broader study on psychosocial factors of creativity and organizational innovation. Studies with this approach are still very scarce. In a bibliographic inquiry in the SciELO database, using advanced search, regional basis, and all indexes, conducted in November 2014, 375 articles were found. Of these, only two articles reported research results on definitions of creativity. The first adopts historical-cultural psychology as its theoretical-methodological basis, with psychology students as its subjects, and makes use of semi-structured interviews (ZANELLA et al., 2003). The second adopts facet theory and conducts a multidimensional analysis of the definitions of creativity obtained through two collective meetings with students of Psychology, Education, and Journalism. They were requested initially to freely record what came to mind upon evoking the word creativity, and later to categorize their mental images, explaining them (BECKER et al., 2001).

The study presented here differs from those previously mentioned, as it does not adopt a specific theoretical focus on creativity and innovation. The analysis focuses on characterizing the key elements of the definitions of creativity and innovation given by workers participating 
Sônia Maria Guedes Gondim, Elisabeth Loiola, Franciane Andrade de Morais \& Silvia Cristina da Costa Dutra

in the research and the identification of their alignment with definitions and theoretical perspectives present in the literature. Understanding the greater or lesser alignment of the workers' conceptions with the theoretical-scientific references that guide research and management practices in the area allows for inferences about barriers and difficulties in successfully carrying out management policies promoting creativity and innovation in contemporary organizations, helping to suggest strategies to mitigate such limitations.

Given the above, the two sections that follow present and discuss concepts of creativity and innovation with regard to the scientific literature on the topics. The method section follows with information about the participants, the instrument, and the procedures for data collection and analysis. Subsequently, the results, the discussion, and the main conclusions of the study are presented.

\section{CREATIVITY}

In the view of Mano and Zagalo (2009), there are many definitions of creativity. By targeting the individual and focusing on divergent thinking, creativity was conceptualized as: (i) an unconscious process in response to sexual instincts; (ii) a result of a chain of associated ideas; (iii) an expression of pre-conscious needs; and (iv) a product of the tendency toward selfrealization in the human species (e.g., ALENCAR; FLEITH, 2003). With this background, the Scholars on this subject stressed, until the 1970s, the profile of creative individuals and the development of programs and techniques facilitating creativity.

The preponderant focus, both on the individual and on divergent thinking, fades with the progress of research and in parallel with social change, and is gradually replaced by a systemic vision of the creativity phenomenon (ALENCAR; FLEITH, 2003; WECHSLER, 1998). There is also an observable shift, from one-dimensional approaches and metrics, toward multidimensional approaches to creativity. Wechsler (1998), for example, seeks escape from the creativity measurement tradition, based on divergent thinking, and proposes a multidimensional measurement model of creativity.

In more recent years, creativity has come to be understood as a set of original and useful answers aimed at solving problems. Originality can be obtained by reorganizing information and inputs, elimination of contradictions and inconsistencies, or can even arise from new ideas. Usefulness, in turn, requires social recognition, thus being dependent on a value judgment (PINHEIRO, 2009). In short, the definition of creativity thus involves three 


\section{CREATIVITY AND INNOVATION AS DEFINED BY WORKERS}

dimensions: the emergence of the idea (rearrangement), the quality of the idea (originality), and the social judgment of the idea (usefulness).

Even with the increased interest in the subject and the knowledge accumulated until this time, a consensus has not been reached on the definition of creativity. Analyses of various concepts and theoretical discussions on the subject (AMABILE, 1990; BODEN, 1994; WECHSLER, 1998) allowed the authors of this article to identify four interrelated aspects and components of the phenomenon, namely: design, development, analysis, and scope.

The definitions of creativity that focus on design vary between claiming to be a conscious process, the result of planned action, or the opposite, an unconscious or even spontaneous process, with little conscious control. The theoretical perspective of Amabile (1990) is set in the first case, by emphasizing the individual motivational effort and also the contextual social factors that allow the development and expression of creativity. Boden (1994), in contrast, directs the focus of the concept of creativity towards computational and cognitive processing models, mainly unconscious and automatic.

Regarding the development of creativity, the definitions can focus on learning, acquisition, and improvement (e.g., ALENCAR; FLEITH, 2010; BRUNO-FARIA, 2003; BRUNOFARIA, VEIGA; MACEDO, 2008; OSBORN, 1963; STERNBERG; LUBART, 1999), or on the stable personal trait, placing it, for example, at the level of intelligence and personality (e.g., AVERILL, 2002; DA COSTA et al., (submitted paper); GUILFORD, 1979).

On taking into account the analysis level of the phenomenon, definitions of creativity range between emphasizing the individual factors (e.g., BONO, 2008) or highlighting situational, interpersonal, and contextual factors (e.g., ALENCAR; FEITH, 2010; AMABILE, 1990). In relation to scope, the definitions highlight the quality of rearranging ideas in useful and adaptive new configurations (e.g., TORRANCE, 1962) or place emphasis on novelty (e.g., OLDHAM; CUMMINGS, 1996; SHIPTON et al., 2006; PARJANEN, 2012).

Publications that discuss the evolution of the concept (e.g., ALENCAR; FLEITH, 2010; HALL, 2010; ISAR; ANHEIER, 2010; LUBART, 2007) state that creativity was regarded as a divine and irrational entity, and went on to acquire importance in psychological, psychoanalytic, and humanistic theories. The focus of creativity in the individual prevailed over time both in the scientific literature, and in the popular imagination (AMABILE, 1996; GUILFORD, 1979; LUBART, 2007; NAKAN; WECHSLER, 2007). The vision of creativity as an act of special individuals, geniuses, is typical of Western culture and reflects 
Sônia Maria Guedes Gondim, Elisabeth Loiola, Franciane Andrade de Morais \& Silvia Cristina da Costa Dutra

characteristics of the nineteenth century, of Romanticism, excluding civilizations in which the relationship between creativity and the individual act was not as strong (HALL, 2010).

The focus on the individual, however, has been reduced by the advancement/progress of studies in the field that point out the need to include contextual and environmental factors in explaining creativity (BRUNO-FARIA et al., 2008; CSIKSZENTMIHALYI, 1996; HENNESSEY; AMABILE, 2010; OLIVEIRA; NAKANO, 2011). In short, the analytical approach of the individual level gave way to a systemic view of creativity which includes the individual, and social and contextual factors (EYSENCK, 1999; GARDNER, 1996; RHODES, 1987; WOODMAN, SAWER; GRIFFIN, 1993).

\section{INNOVATION}

In the organizational literature, the constructs of creativity and innovation are commonly found to be associated. For Schumpeter $(1961$; 1982) and the neo-Schumpeterians (LUNDVALL, 2001; PEREZ, 2004), innovation means doing something new or in a new way. Innovation is expressed in new goods, new markets, physical technologies, but also in management, organizational, and social technologies. The generation and especially the diffusion of innovations explain the cyclical behavior of economies, generating waves of development (SCHUMPETER, 1961). Also, innovative organizations commonly survive longer, occupying leading positions in their fields (PEREZ, 2004; SCHUMPETER, 1982). To qualify as innovation, processes, products, and market-related, organizational, and social technologies must be new or present significant improvements for organizations (OSLO MANUAL, 2005).

Innovation is considered an organizational and social phenomenon that involves exchanges between different actors in the organization and the systemic environment in order to turn creative problem solutions and ideas into viable new products, processes, or services, thus contributing to organizational development. In addition, innovation brings a sustainable component, since its value is also linked to development, to feasibility, and to market acceptance. In short, innovation depends on a social assessment process, i.e., on perceptions, knowledge, and value judgments (STIERAND; DORFLER; MACBRYDE, 2014). At this point, a closer relation between innovation and creativity becomes evident, as both require social legitimacy, novel in character, i.e., they are subject to social judgment of their value. The neo-Schumpeterian perspective (LUNDVALL, 2001; PEREZ, 2004) advances in 


\section{CREATIVITY AND INNOVATION AS DEFINED BY WORKERS}

comparison with the formulations of Schumpeter $(1961 ; 1982)$, in emphasizing the social and systemic-interactive nature of the innovation process, especially in relation to the set of organizational actors composing the innovation systems. Besides considering the role of the company as the principal agent of innovation, the neo-Schumpeterians also take into account it as a part of a more extensive system.

This system involves a network of relationships between social agents, typical of a country or region, and includes relationships between businesses, educational and research institutions, the existence of public and / or private infrastructure, national and international economies, in addition to local socio-historical-cultural aspects associated with organizational, legal, and normative characteristics. These formulations lend more complexity to the process and environments of innovation (GUIMARÃES, 2011; MARONE; GONZALEZ DEL SOL, 2007). Also owing to the neo-Schumpeterian tradition is the differentiation between radical innovations - a rupture with the existing, products, processes, organizational forms, markets, etc. - and incremental ones - improvement of products, processes, management models, inputs, and forms of penetrating markets.

Although widespread, the Schumpeterian definition of innovation and the neo-Schumpeterian postulates about the innovation environment coexist and compete for space with many other definitions, postulates, and related concepts. Studies in the areas of management and sociology of organizations have shown, for example, that creativity and innovation emerge at the outer edges of systems, and not at their centers, and are conditioned by social, cultural, and political forces. Revolutionary periods are characterized by greater creativity, and the organizations that show better performance and capacity for survival are those that decide to break with the structural and cultural inertia of existing routines (ISAR; ANHEIER, 2010). There is here a differentiation from the Schumpterian premisses, that link the emergence of innovations with periods of low growth for economies, and assert that it is the emergence of these innovations, and especially their diffusion via social and productive structures, that help in overcoming times of crisis.

From the point of view of the authors of this article, the analysis of the definitions of innovation found in the literature led to identifying six key aspects: planning, usefulness, result, improvement, feasibility, and novelty. Innovation in organizations involves a formal planning process, i.e., it is an intentional and planned action for transformation, involving new or improved processes and products (OTTENBACHER; HARRINGTON, 2007). The second and third key aspects are the result and the usefulness (GOEPEL; HÖLZLE; 
Sônia Maria Guedes Gondim, Elisabeth Loiola, Franciane Andrade de Morais \& Silvia Cristina da Costa Dutra

KNYPHAUSEN-AUFSE $\beta, 2012$ ). This means that in addition to planning being directed to a tangible result in terms of processes or products, the pragmatic character of innovation must be visible (WEST; FARR, 1990). Innovation requires a feasibility analysis of implementation in the short, medium, or long term (fourth key aspect) (AMABILE, 1996; MUMFORD, HESTER; ROBLEDO, 2012), clearly showing its role in improvement (enhancement of something existing - fifth key aspect) (LOVE; ROPER, 2004) or a quality of novelty (breaking with previously established standards - sixth key aspect) (DAMANPOUR; ARAVIND, 2012; JIMÉNEZ-JIMÉNEZ; SANZ-VALLE, 2008; SCHUMPETER, 1961).

Some authors, however, combine creativity and innovation in a single definition, considering them fruits of an interactive process for generating creative knowledge and its application, to create new value (PARJANEN, 2012; SHIPTON et al., 2006), which suggests, more clearly, the interdependence between both phenomena (BRUNO-FARIA, 2003). It should be noted that even in this case, creativity is treated as necessary, but not sufficient, for innovation (WEST; SACRAMENTO, 2012).

The conceptual characterization of creativity and innovation, in which the aim was to highlight its key aspects, formed the basis for the qualitative analysis of the definitions given by workers who participated in a broader study on psychosocial factors associated with creativity and organizational innovation. The focus of this article concerns the analysis of the key elements of these definitions and their alignment with definitions and theoretical perspectives present in the specialized literature. It is hoped that the results contribute to improving people management policies to enhance worker creativity and organizational innovation.

\section{METHOD}

\subsection{Participants}

The study included 231 workers from Portuguese-, Spanish-, and Basque-speaking countries, with ages from 22 to 75 years $(m=45 ; s d=10.56)$. Thirty-two percent $(32 \%)$ answered the questionnaire in Portuguese, and 68\% in Spanish and Basque. The duration of the workers' experience ranged from 1 to 45 years ( $m=27$ years). Regarding gender, 52\% were women. Regarding educational level, $10 \%$ had a secondary level, $32 \%$ had a college degree, and $57 \%$ were at the graduate level. 


\section{CREATIVITY AND INNOVATION AS DEFINED BY WORKERS}

The majority, $72 \%$, worked in public organizations, $22 \%$ in private organizations, only $4 \%$ were linked to the third sector (non-profit), and $2 \%$ did not specify.

\subsection{Instrument}

The inventory of Factors for Innovation in the Organization (F.I.N.O.) developed by da Costa et al. (2014) was used in this study. This is a self-report measure with 38 questions, created based on meta-analysis studies on the subject, which evaluates the perception of individual factors (e.g., self-efficacy), group factors (e.g. interaction in the team, relationship with the leader), and contextual factors (e.g., climate, job characteristics, support) related to organizational creativity and innovation. The instrument is currently in the process of validation. The questionnaire has versions in three languages: Portuguese, Spanish, and Basque. For purposes of this article, only two open questions were analyzed, where participating workers were asked to write, in a nutshell, the meaning they attributed to organizational creativity and to organizational innovation.

\subsection{Procedure}

The inventory was completed by participating workers who received the invitation via email, which included a link to access the electronic version of the questionnaire. The sample was not random, being composed using the snowball technique. The criterion for inclusion in the sample was to be working, as an employee. The participants came from diverse organizations (industry, commerce, and education). The questionnaire was presented only upon the participant's acceptance of the Free and Informed Consent Terms. Data collection took place in 2014 .

\subsection{Data Analysis}

The qualitative data analysis software ATLAS.ti was used. This tool was chosen because of the resources it provides for the treatment of textual information and the possibility of extracting quantitative information from the data. Descriptive statistics were used to characterize the participants and to help with the interpretive inferences. The sociodemographic and profile information of the participants served for identification and characterization of the respondents, since the objective was not to carry out comparative analyses between countries and languages. 
Sônia Maria Guedes Gondim, Elisabeth Loiola, Franciane Andrade de Morais \& Silvia Cristina da Costa Dutra

Although qualitative studies recommend that the coding and categorization system should emerge from the data (CHARMAZ, 2006), it was decided to make use of a categorial system originating from a theoretical-conceptual basis, since the main objective was to evaluate the alignment between the definitions of workers and the literature. Chart 1 shows the categories used in the analysis.

Chart 1 - Categories and subcategories of creativity and innovation

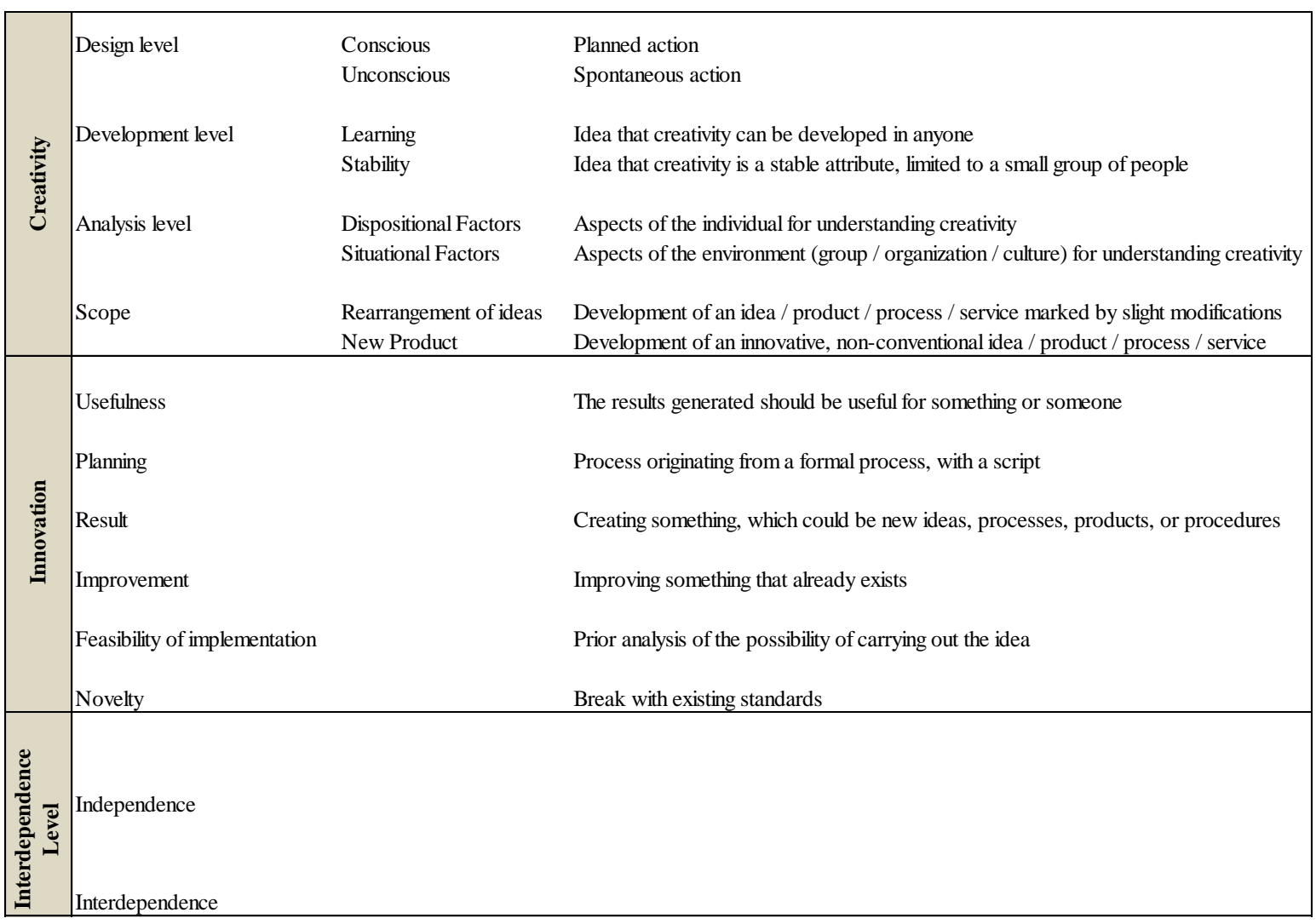

Source: Research data (2015)

To ensure the suitability of the analytical categories for the three groups of respondents, the first step was an analysis of the definitions from the Portuguese-speaking participants, by two independent judges. In sequence, the same was done with the definitions from the Spanish speakers and the Basque. The answers in Basque were translated into Spanish by researchers with a mastery of both languages before applying the categorial system analysis. The categorial system proved to be suitable for the three groups of respondents, allowing inclusion of all the definitions given. It was noted, however, that some definitions may carry one, two, or three elements that allow for including and computing them numerically in more than one category. 


\section{CREATIVITY AND INNOVATION AS DEFINED BY WORKERS}

Markings were made in the definitions, for each category, using the ATLAS.ti coding tool. The list of definitions related to each of the categories generated quantitative indicators shown in Figures 1 and 2.

\section{RESULTS}

Figure 1 illustrates the results of the analysis for the definitions of creativity given by the respondents. It is noted, in Figure 1, that the workers' definitions emphasize two categories: scope and focus of the analysis.

Figure 1 - Categorization of the definitions of creativity from the workers surveyed

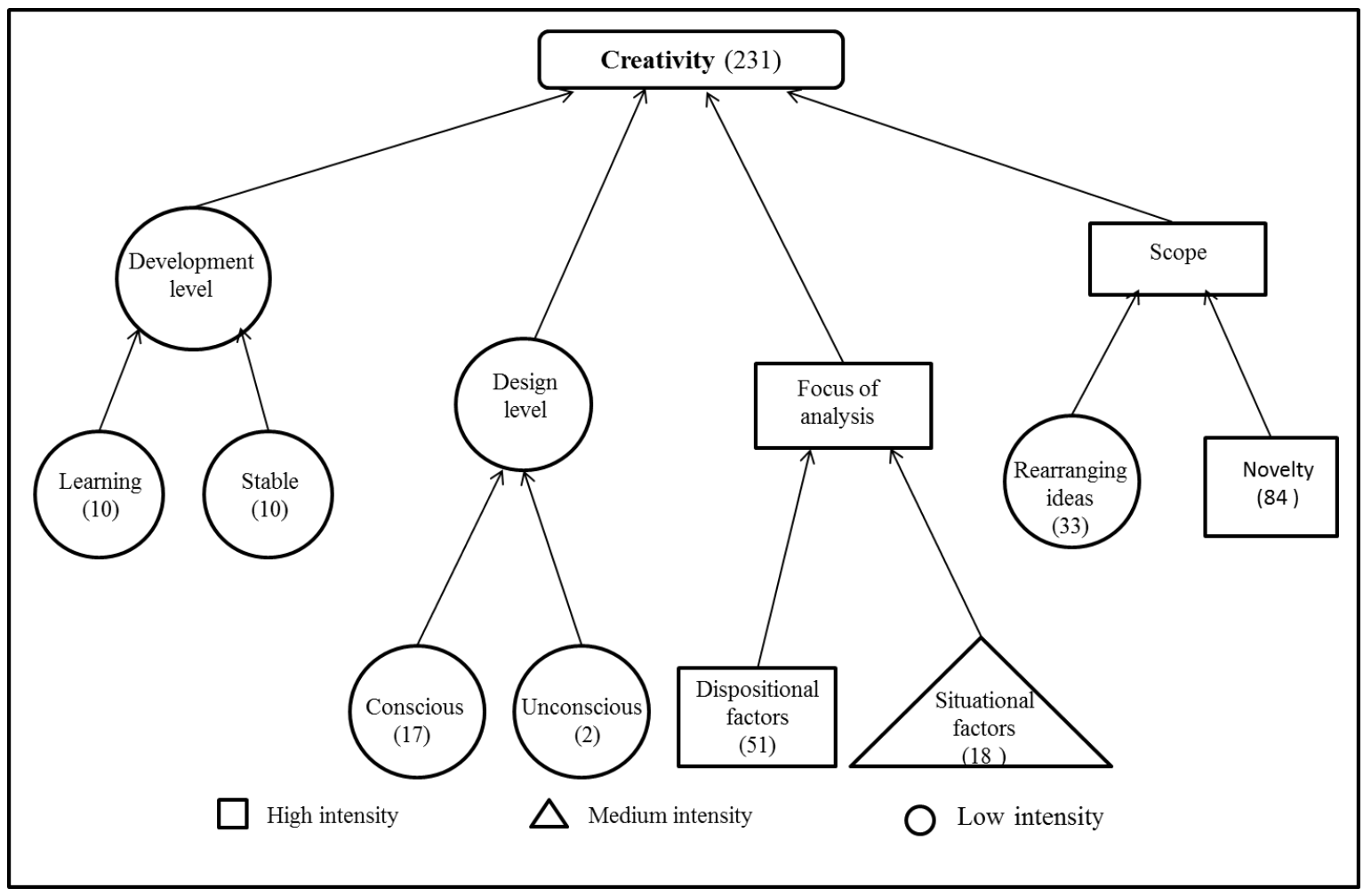

Source: Research data (2015)

Note: The number of respondents was 231. Six (6) definitions were not included in the analysis, because they did not actually mention definitions of creativity.

Intensity took into account the total number of elements contained in the definition and the proportionality.

High intensity $=22.6 \%(n=51)$ and $37.3 \%(n=84)$, Medium intensity $=14.6 \% \quad(n=3)$, Low intensity $=4.4 \% \quad(n=10), 4.4 \% \quad(n=10), 7.5 \% \quad(n=17), 0.8 \% \quad(n=2) \quad$ and $8 \% \quad(n=18)$. In relation to scope, creativity is associated with novelty $(\mathrm{N}=84)$, more than with the 
Sônia Maria Guedes Gondim, Elisabeth Loiola, Franciane Andrade de Morais \& Silvia Cristina da Costa Dutra

rearrangement of ideas $(\mathrm{N}=33)$. The following examples ${ }^{1}$ help illustrate the nature of novelty: "Having new ideas, what was not analyzed or imagined before" (Pt); "It is the ability to use knowledge in the formation of new products and process" (Pt); "The capacity to generate or see something in a new way, different from what is traditionally and normally produced or seen with those elements/instruments" (Sp); "The development of ideas, concepts, or experiments without precedents, or that based on certain antecedents have little relation with them or substantially transcend them." (Sp); The following examples illustrate the rearrangement of ideas: "Creativity means giving a different use to existing products" (Pt); "It's the ability to identify problems and propose solutions, not necessarily innovative" (Pt); "Using the tools already known to find a path, process, and/or solution in a novel way and different from the usual." (Sp); " Novel changes in already known products or modification of processes in which their essentials are not modified" (Sp);

For the second category, focus of analysis, the prevalence is shown of creativity analysis based on dispositional factors $(\mathrm{N}=51)$ more than situational factors $(\mathrm{N}=18)$. In the first case, dispositional factors, creativity would originate from individual factors such as ability, motivation, adaptability, and personality traits, for example: "In professional practice, being creative means being proactive, even amidst the improvised circumstances that we sometimes encounter within the organizational context "(Pt); "(Creativity is) determination and attitude" $(\mathrm{Pt})$; "It is always an individual characteristic" (Sp); "The internal capacity to generate new ideas for improving teaching, research, and transfer" (Sp); "Implies adaptability, freshness, resolving situations, confrontation, being brave and innovating" (Sp).

The definitions that stressed situational factors mention that creativity would be the result of the environment and the culture, such as connection with peers, dialogue climate, development of teamwork, organizational structure, in addition to variables on organizational support and encouragement for autonomy: "Refers to the space and encouragement given to coworkers so that through their ideas they can contribute to the continuous improvement of a process or a system, etc." (Pt); "Permission for generating new ideas" (Pt); "Creativity is the opportunity to express ideas and opinions that lead to problem solving in a manner different from the conventional or that expected by most people" (Pt); "It is having autonomy to

\footnotetext{
${ }^{1}$ Examples of definitions in Portuguese $(\mathrm{Pt})$ and in Spanish $(\mathrm{Sp})$ were used. We point out that the definitions in Basque were translated into Spanish by the authors who had a mastery of both languages. Therefore, some examples in Spanish also include respondents who responded in Basque. There is no need to differentiate these, given that in the region of Spain where the data was collected, the respondents make use of both languages.
} 


\section{CREATIVITY AND INNOVATION AS DEFINED BY WORKERS}

perform your activities, when we have autonomy things flow better" (Pt); "Flexibility in the structure and organization" (Sp); "Trying to motivate and encourage student participation in seminars and design new materials for this" (Sp).

The remaining categories, Development level (stable - $\mathrm{N}=10$; and learning - $\mathrm{N}=10$ ); and Design level (conscious - $\mathrm{N}=17$; and unconscious - $\mathrm{N}=2$ ) are less present in the definitions of participants in general. Opinions are divided between conceiving of creativity as a stable personal trait - "It's an ability of people" (Sp); "A point above the curve, that is, creativity is a skill that makes the creative stand out with practical and / or aesthetically beautiful solutions" (Pt); "Creativity is the ability of an individual to create something new" (Sp) - or as the result of learning - "Exposing your constructive ideas and infecting a team, making something productive happen" (Pt); "In our school of fine arts, creativity is something always present. In each exercise we assign, it is implicit, in both the proposal and the expected response. Its existence should be encouraged every day by establishing close relationships between student and teacher, to find a way to facilitate its development "(Sp).

With respect to the design level category, the definitions highlight more the conscious character of the creative process, than the unconscious: "It is managing to think of effective solutions to the problems faced, i.e., to think of the best possible solutions suitable for solving these problems" (Pt); "A primarily cognitive process from one or more members of the organization" (Sp); "Designing questions following a logical reasoning that questions the current knowledge about a field" (Sp).

After having done the analysis of the definitions of creativity, we must now consider the definitions of innovation. Thus, Figure 2 shows the conceptions of innovation from the workers surveyed, according to the previously described categories: usefulness, planning, results, and feasibility of implementation, improvement, and novelty. The results indicate that the definitions from the participants are strongly associated with novelty $(\mathrm{N}=81)$ : "Do something new; something that has not yet been done" (Pt); "Do something in a new, distinct way" (Sp); "Innovation is the ability to create a new product, unprecedented, that does not yet exist" (Pt); "(Innovation is) being able to think of something out of the ordinary, outside the commonplace, something that other employees have not yet thought of, or that would be surprising to them" (Pt); "Creating tools or models that did not previously exist and that can be a positive contribution in the work context" (Sp).

The concept of innovation as a process improvement ranks second $(\mathrm{N}=41)$ : "The ability to implement changes, improvements, or new ways of working, in existing activities" $(\mathrm{Pt})$; 
Sônia Maria Guedes Gondim, Elisabeth Loiola, Franciane Andrade de Morais \& Silvia Cristina da Costa Dutra

"Innovation means changing the company's processes using modern solutions" (Pt); "Innovation consists of adopting technologies that add new possibilities to a technology already known or disclosed" (Pt); "Changing something that already exists, improving it" (Sp); "Modifying existing procedures, intending to improve on something" (Sp).

Figure 2 - Categorization of the definitions of innovation as perceived by the workers surveyed

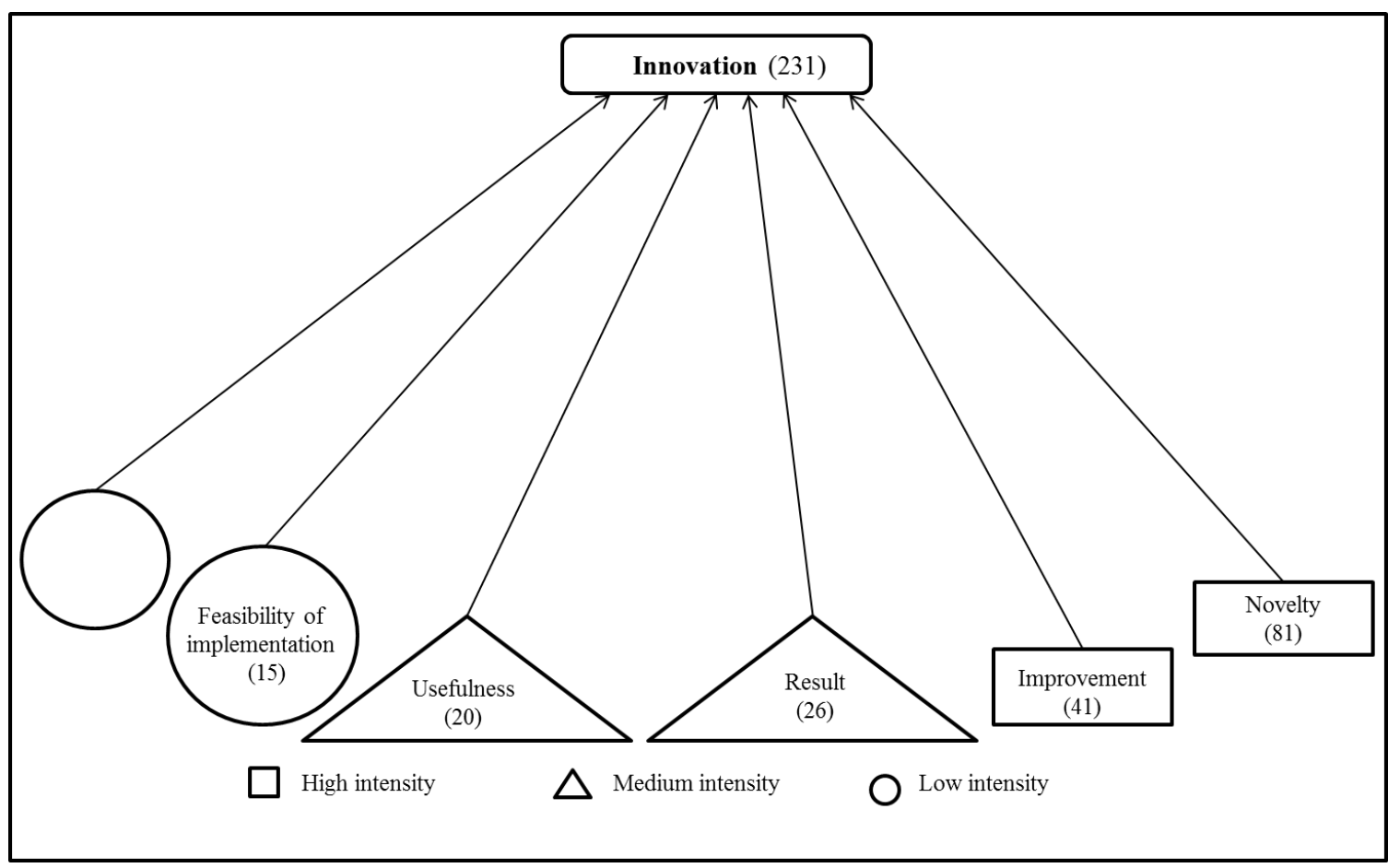

Source: Research data (2015)

Note: The number of respondents was 231. Forty-one (41) definitions were included in a separate category, "other", because they did not actually mention definitions of innovation.

Intensity took into account the total number of elements contained in the definition and the proportionality.

High intensity $=22 \%(\mathrm{n}=41)$ and $43 \%(\mathrm{n}=81)$, Medium intensity $=10.5 \%(\mathrm{n}=20)$ and $13.7 \%$ $(\mathrm{n}=26)$, Low intensity $=5.3 \% \quad(\mathrm{n}=6)$ and $3.2 \%(\mathrm{n}=15)$

The result $(\mathrm{N}=26)$ and usefulness $(\mathrm{N}=20)$ categories appear with medium intensity. The result may be a product or process capable of differentiating the organization: "Innovation is the capacity to create new processes or materials that will differentiate the organization from the rest" (Pt); "(...) Providing a better position of the organization in the market" (Pt); "Something 


\section{CREATIVITY AND INNOVATION AS DEFINED BY WORKERS}

that arouses the curiosity of its customers by obtaining results" (Pt); "Design and develop new behavioral strategies and products" (Sp); "Adapt or adopt new processes, technologies, and resources in general, to improve the capacity or performance of the organization" (Sp); "Create new products, processes, services, etc. to achieve an improvement in quality, performance, or net profit" (Sp).

Usefulness highlights the possibility of being able to develop people and the organization, and instigate useful, revolutionary, and context-adaptive changes: "Creativity, in the context of the organization, is based on transforming any resource into goods or services, which may be useful for the company in all aspects "(Pt); "To innovate is to do something new that allows us to develop as human beings and develop our organization" (Sp); "Innovation is the ability to deliver products and solutions that can revolutionize the day-to-day within the business or for the consumer" (Pt); "Seek novel responses, in the sense that they are appropriate responses to the social and technological changes that are occurring in the environment" (Sp).

Aspects relating to the feasibility of implementation $(\mathrm{N}=15)$ and to formal planning $(\mathrm{N}=6)$, which would indicate innovation to be an important point in the competitive strategy of the organization, were hardly mentioned by workers, in a direct manner: "Ideas put in practice, in a continuous way "(Pt); "The predisposition/internal capacity to materialize the ideas and convert them into products and services transferable to the entire academic community, and the social and productive environment" (Sp); "Having practical possibilities, material resources, [...]. and power to implement some of the new proposed solutions to problems and tasks that are carried out either in teaching, research, or management"(Sp); "The search for new challenges and paths to achieve them within a well-planned strategy" (Sp).

\section{DISCUSSION}

The results of this study show that, although the phenomenon of creativity has interconnected constituent elements (AMABILE, 1990; BODEN, 1994; WECHSLER, 1998), workers perceive some of these elements more clearly than others. The definitions relate especially to the scope of the concept of creativity (rooted in the concepts of novelty and rearrangement of ideas) or the focus of analysis supported by dispositional factors. This shows that situational factors, as well as design and development elements, are poorly perceived by workers, confirming a static view of creativity, while the current theories point to a dynamic and context dependent phenomenon (EKVALL, 1996). The literature on creativity in 
Sônia Maria Guedes Gondim, Elisabeth Loiola, Franciane Andrade de Morais \& Silvia Cristina da Costa Dutra

organizations shows, even, the role of human resources management in building a work environment conducive to creativity and innovation (RODRIGUES; VELOSO, 2013).

Regarding innovation, there is also more emphasis on some of its constituent elements novelty and improvement - than on others, with little emphasis on the viability of implementation and planning.

Analysis of the workers' definitions allows us to infer that creativity and innovation are associated with the character of novelty in the development of an idea / product / process / service, which converges with the definition of several authors such as Amabile (1996), Ottenbacher and Harrington (2007), and Shipton et al. (2006). The categories, new product (for creativity) and novelty (innovation), which were highlighted for the two concepts investigated, reveal a syntactic approximation, both making reference to the development of something that breaks with the established standards. The interdependence between the concepts is therefore expressed in the definitions given by the workers, in the interrelation shown by reference to the new. And this is clearly expressed in Parjanen (2012) for whom innovation in the organization is the result of the creation, dissemination, and application of new knowledge; here creativity is the component of the organization that increases its competitive advantage by enabling innovation.

While on the one hand, it appears that novelty is present in the two concepts, on the other, planning, as a key aspect for the organization to develop innovation (OTTENBACHER; HARRINGTON, 2007; SCHUMPETER, 1982; WEST; FARR, 1990) is practically absent from the workers' definitions. What are the possible implications of this absence? One would be to conceive of innovation as a spontaneous and improvised psychological manifestation stemming from personal psychological attributes, inhibiting ordained actions, to improve organizational creativity and innovation processes. The reduction of creativity and innovation to individual attributes is aligned with a traditional view of psychology considered already outmoded by Alencar and Feith (2010). Another implication of this is to assume that the ability to innovate and create is exhausted by the adoption of brainstorming practices for idea generation and problem solving (OSBORN, 1963). Both of these implications inhibit organizational planning efforts for guiding actions and interventions in work processes toward improving process and results indicators in creativity and innovation.

The theories that place an emphasis on contextual and situational factors emphasize that organizations invest in an environment that can promote interactive processes with the 


\section{CREATIVITY AND INNOVATION AS DEFINED BY WORKERS}

objective of increasing the exchange of ideas and learning. The expectation is that sharing assists in generating new ideas to be implemented in innovative products (ALENCAR, 1996; AMABILE, 1990; BRUNO-FARIA, 2003; BRUNO-FARIA et al., 2008; ZHOU; KOEVER, 2014). The beliefs in personal attributes more than contextual ones can act to discourage the engagement of employees in organizational actions directed at creating a conducive environment for innovation. As Bruno-Faria (2003) asserts, creativity and innovation operate as an integrated system, and the lack of clarity of workers and organizations concerning this involved relationship imposes barriers to effective organizational innovation policies.

One should not disregard, however, that the general profile of workers who participated in the study may help explain the results. The high mean age (45 years) and the broad work experience (27 years) may indicate their being a generation that entered organizational contexts in a generally less competitive environment, innovation and creativity not being considered part of the organizational strategy. Creativity and innovation were then more easily perceived as a consequence of personal traits and initiatives, rather than carefully planned actions by organizations to form work teams and create supportive environments. However, this interpretation must be qualified, because, according to da Costa et al. (article submitted), recent meta-analysis studies found an effect of age and work experience in creativity. What can be said in this case is that the knowledge accumulated through age and experience can help in the formation of a repertoire that contributes heuristically to new mental arrangements.

It is also observed that some definitions given by the participants more clearly mention a link between creativity and innovation, although this has occurred in a small number of cases (15 of 231). However, this does not suggest that the surveyed workers realize that creativity and innovation are independent phenomena. Two possible explanations for the limited connection between the concepts made by the participants may be: (i) generational insertion in a minimally competitive organizational environment in which the relationship between creativity and innovation were not central aspects, and (ii) error induced by the research questionnaire itself, which asked participants to present their definitions in separate spaces.

In fact, the literature points to an interdependence between these concepts, with creativity being a condition for innovation to succeed (BASSETT-JONES, 2005; MARKS; HUZZARD, 2008). In this sense, an organizational climate favorable to the development of established organizational practices and policies may be factors contributing to the development of both creativity and innovation (DA COSTA et al., 2014; RODRIGUES; VELOSO, 2013).

REAd | Porto Alegre - Edição 82 - Nº 3 - setembro/dezembro 2015 - p. 549-575 
Sônia Maria Guedes Gondim, Elisabeth Loiola, Franciane Andrade de Morais \& Silvia Cristina da Costa Dutra

While on one hand, each of these concepts is associated with research areas in different degrees of maturity; on the other, there is a need to seek convergence and promote a connected conceptual understanding, since they revolve around common aspects: the new, the change, the personal and group initiative, and the practices and environments promoted by organizations (BRUNO-FARIA; VARGAS, 2013). Thus, this study presents a contribution both in pointing out specifics in the perception that workers have of creativity and innovation, and in showing that there are common elements in the discourses that they establish about such concepts. If the theoretical dialogue between creativity and innovation is already present in the reviewed literature, the present study shows that this possibility of convergence is also found in practice.

\section{CONCLUSIONS}

As to the contribution that the analysis of the definitions of workers can bring to the organizational management policies, three aspects are highlighted. The first clarifies the fact that the workers understand that creativity and innovation are intended to bring novelty to the organizational context, creativity contributing to the rearrangement of ideas, and innovation to improving processes. Such recognition makes it easier to plan management actions in the context of the work teams climate (including leadership) and job design, encouraging divergent thinking, the association of ideas, convergent synthesis, and individual and group imagination. The assumption is that there will be impacts on creativity indicators (creative capital). This recognition also provides a basis for planning processes aimed at selecting proposals for products or processes stemming from individual and group creativity, judging them, and implementing them such that they have application and usefulness in organizational improvement (innovation capital).

The second aspect highlights the fact that the workers do not view innovation as the result of a planned organizational strategy, which tends to weaken its engagement in actions for innovation and creativity adopted in the organization, probably because they are perceived as fragmented and limited in scope. Enhancing creativity and innovation in organizations, as pointed out in the previous paragraph, requires organizational management to take the starring role, elaborating short, medium, and long term planning that align the strategic vision of the organization with actions at the level of structure, processes, working conditions, teams, and 


\section{CREATIVITY AND INNOVATION AS DEFINED BY WORKERS}

workers. The recognition of the workers, as having alignment and connection with the actions to achieve innovation objectives, strengthens motivational engagement.

The third and final aspect to be emphasized refers to the level, development of creativity. The workers' definitions suggest that creativity is seen both as a stable personal attribute and as a result of learning. To assume that creativity is a stable personal attribute weakens the worker's engagement in tasks that require new and different solutions, and inhibits individual expression in work teams. After all, those who do not see themselves as creative, and facing teammates whom they consider more talented, avoid the risk of publicly expressing their ideas, reducing possibilities of interaction and learning for innovation. Training work team leaders to facilitate a climate less critical and more stimulating expands the possibilities of collaborative learning and promotes self-confidence in the potential of the individual in contributing effectively to creativity.

As a limitation of this study, there is the fact that the data collection was done through a structured instrument and was answered electronically, which does not allow for in-depth responses from each study participant. However, the decision to collect the data through open questions in the questionnaire allowed us to achieve a broader sample than what could hardly be obtained in individual interviews. As an agenda for future studies we suggest conducting research in different sectors of the economy, in order to identify possible differences in the concepts of creativity and innovation according to the context in which the workers are situated. We also suggest quantitative studies to test models that empirically relate such concepts, indicating their features and interfaces.

\section{REFERENCES}

ALENCAR, E. M. L. S. A gerência da criatividade: abrindo as janelas para a criatividade pessoal e nas organizações. São Paulo: Makron Books, 1996. 124 p.

ALENCAR, E. M. L. S.; FLEITH, D. S. Barreiras à criatividade pessoal entre professores de distintos níveis de ensino. Psicologia: Reflexão e Crítica, Porto Alegre, v. 16, n. 1, p. 63-69. 2003. Available from: <http://www.scielo.br/scielo.php?script=sci_arttext\&pid=S0102$79722003000100007 \& \operatorname{lng}=$ en\&tlng=pt10.1590/S0102-79722003000100007/>. Access on November 22, 2014.

ALENCAR, E, M. L. S.; FLEITH, D. A medida de criatividade: possibilidades e desafios. In: ALENCAR, E. M. L. S.; BRUNO-FARIA, M. F.; FLEITH, D. S. (Org.). Medidas de criatividade: teoria e prática. Porto Alegre: Artmed, 2010. p. 11-34. 
Sônia Maria Guedes Gondim, Elisabeth Loiola, Franciane Andrade de Morais \& Silvia Cristina da Costa Dutra

AMABILE, T. M. Within you, without you: Towards a social psychology of creativity and beyond. In: RUNCO, M. A.; ALBERT, R. S. (0rg.). Theories of creativity. Newbury Park: Sage, 1990. p. 61-91.

AMABILE, T. M. Creativity and innovation in organizations. Boston: Harvard Business School, 1996. v. 5.

AVERILL, J.R. Inteligência, emoção e criatividade: da tricotomia à trindade. In: BAR-ON, R.; PARKER, J.D.A. (Org.). Manual de inteligência emocional: teoria e aplicação em casa, na escola e no trabalho. Porto Alegre: Artmed, 2002. p. 207-221.

BASSETT-JONES, N. The paradox of diversity management, creativity and innovation. Creativity and Innovation Management, v. 14, n. 2, p. 169-175, May. 2005. Available from $<$ http://onlinelibrary.wiley.com/doi/10.1111/j.1467-

8691.00337.x/abstract;jsessionid=AD4B22A56451389D0434A4FC3D7CBAB9.f04t0

$>$ Access on November 22, 2014.

BECKER, M. A. A. et al. Estudo exploratório da conceitualização de criatividade em estudantes universitários. Psicologia: Reflexão e Crítica, Porto Alegre, v.14, n.3, p.571-579. 2001. Available from: <http://www.scielo.br/scielo.php?script=sci_arttext\&pid=S0102$79722001000300012 \& \operatorname{lng}=$ en\&nrm=iso>. Access on November 22, 2014.

BODEN, M. A. La mente creativa: mitos y mecanismos. Barcelona: Gedosa editorial, 1994. $404 \mathrm{p}$.

BONO, E. O pensamento Lateral. Cascais: Editora Pergaminho, 2008. p. 272

BRUNO-FARIA, M. F. Criatividade, inovação e mudança organizacional. In: LIMA, S.M.V. (Org.). Mudança organizacional: teoria e gestão. Rio de Janeiro: FGV, 2003. p. 111-142.

BRUNO-FARIA, F.; VARGAS, E. R. Inovação, criatividade e empreendedorismo. Revista Psicologia, Organizações e Trabalho, Florianopolis, v.13, n.3, p. v-vi, Sep/Dec. 2013. Available from: < http://pepsic.bvsalud.org/scielo.php?script=sci_arttext\&pid=S1984$\underline{66572013000300002 \& \operatorname{lng}=p t \& t \operatorname{lng}=p t}>$. Access on November 22, 2014.

BRUNO-FARIA, M. F.; VEIGA, H. M. S.; MACEDO, L. F. Criatividade nas organizações: análise da produção cientifica nacional em periódicos e livros de Administração e de Psicologia. Revista Psicologia: Organizações e Trabalho, Florianopolis, v.8, n.1, p. 142-163, Jan/June. 2008. Available from: 


\section{CREATIVITY AND INNOVATION AS DEFINED BY WORKERS}

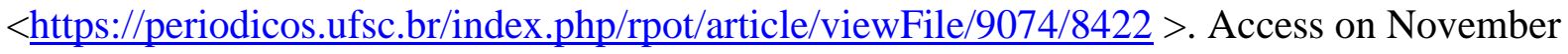
$22,2014$.

CHARMAZ, K. Constructing grounded theory: a practical guide through qualitative analysis. London: Sage Publications, 2006. 208 p.

CSIKSZENTMIHALYI, M. Creativity: flow and the psychology of discovery and invention. New York: Harper Perennial, 1996. 456 p.

DA COSTA, S. et al. Factores favorables a la innovación en las organizaciones: una integración de meta-análisis. Revista Psicología del trabajo y de las organizaciones, Madrid, v.30, n.2, p. 67-74, 2014. Available from: <

http://apps.elsevier.es/watermark/ctl_servlet?_f=10\&pident_articulo=90337433\&pident_usua $\underline{\text { rio }=0 \& \text { pcontactid }=\& \text { pident } \_ \text {revista }=370 \& \text { ty }=14 \& \text { accion }=\text { L\&origen=jwop } \% 20 \& w e b=j w o p . e l}$ $\underline{\text { sevier.es\&lan }=\text { es\&fichero }=370 v 30 \mathrm{n} 02 \mathrm{a} 90337433 \mathrm{pdf001} . \mathrm{pdf}}>$. Access on November 22, 2014.

DA COSTA, S. et al. Factores Personales de la creatividad: una integración de Meta-Análisis. Personal factors of creativity: an integration of Meta-Analysis. Journal of Work and Organizational Psychology. No prelo.

DAMANPOUR, F.; ARAVIND, D. Organizational structure and innovation revisited: from organic to ambidextrous structure. In; MUMFORD, M. D. (Org.). Handbook of organizational creativity. USA: Eleaser, 2012. p. 483-514.

EKVALL, G. Organizational climate for creativity and innovation. European Journal of Work and Organizational Psychology, v.5, n.1, 105-123, Jan. 1996. Available from:

http://www.academia.edu/673511/Organizational_climate_for_creativity_and_innovation.

Access on November 22, 2014.

EYSENCK, H. As formas de medir a criatividade. In: BODEN, M.A. (Org.). Dimensões da criatividade. Porto Alegre: Artes Médicas, 1999. p. 203-225.

GARDNER, H. Mentes que criam. Porto Alegre: Artes Médicas, 1996. 386 p.

GOEPEL, M.; HÖLZLE, K.; KNYPHAUSEN-AUFSEß, D.Z. Individuals’ Innovation Response Behaviour: A Framework of Antecedents and Opportunities for Future Research. Creativity and Innovation Management, v. 21, n.4, p. 412-426, Nov. 2012. Available from: < http://onlinelibrary.wiley.com/doi/10.1111/caim.2012.21.issue-4/issuetoc $>$. Access on November 22, 2014. 
Sônia Maria Guedes Gondim, Elisabeth Loiola, Franciane Andrade de Morais \& Silvia Cristina da Costa Dutra

GUILFORD, J. P. Way beyond the IQ. Guide to improving intelligence and creativity. Buffalo, NY: Creative Education Foundation, 1979. 186 p.

GUIMARÃES, S. K. Produção do Conhecimento Científico e Inovação: desafios do novo padrão de desenvolvimento. Caderno de Recursos Humanos, Salvador, v.24, n.63, Dec. 2011. Available from: <http://www.scielo.br/scielo.php?script=sci_arttext\&pid=S0103$49792011000300001 \& \operatorname{lng}=\mathrm{en} \& n r m=\mathrm{iso}>$. Access on November 22, 2014.

HALL, S. (2010). Foreword. In: ANHEIER, R.; ISAR, Y.R. (Eds.). The Cultures and Globalization Series 3: cultural expression, creativity and innovation. London: SAGE Publications Ltd.. p. IX - XII. Available from: < http://knowledge.sagepub.com/view/cultural-expression-creativity-andinnovation/SAGE.xml> Access on November 22, 2014.

HAMMOND, M; GUY, G.; HOOTEGEM, G. Predictors of Individual- Level Innovation at Work: A Meta-Analysis. Psychology of Aesthetics, Creativity, and the Arts, Washington, v.5, n.1, p. 90-105. Feb. 2011. Available from: < http://www.academia.edu/2411133/Job_Design_and_Innovative_Work_Behavior_One_Size Does_Not_Fit_All_Types_of_Employees> Access on November 22, 2014.

HENNESSEY, B.; AMABILE, T. Creativity. Annual Review of Psychology, California, v. 61, p. 569-598, Jan. 2010. Available from: <

http://www.annualreviews.org/doi/full/10.1146/annurev.psych.093008.100416 >Access on

November 22, 2014.

HÜLSHEGER, U.; ANDERSON, N.; SALGADO, J. Team-Level Predictors of Innovation at Work: A Comprehensive Meta-Analysis Spanning Three Decades of Research. Journal of Applied Psychology, Washington, v.94, n.5, Sep. 2009. Available from: <

http://psycnet.apa.org/index.cfm?fa=buy.optionToBuy\&id=2009-12532-002> Access on November 22, 2014.

HUNTER, S.; BEDELL, K.; MUMFORD, M. D. Climate for creativity: a quantitative review. Creativity Research Journal, v.19, n.1, p. 69-90. Dec. 2007. . Available from:

$<$ http://wonderous.info/blog/wp-content/uploads/2014/08/climate.pdf $>$ Access on November $22,2014$.

ISAR, Y. R.; ANHEIER, H. K. Introduction. In: ANHEIER, R., ISAR, Y.R. (Eds.). The Cultures and Globalization Series 3: cultural expression, creativity and innovation. London: SAGE Publications Ltd. p. 1-20. 2010. Available from: <http://www.sagepub.com/upmdata/46996_Anheier_Intro.pdf $>$ Access on November 22, 2014. 


\section{CREATIVITY AND INNOVATION AS DEFINED BY WORKERS}

JIMÉNEZ-JIMÉNEZ, D.; SANZ-VALLE, R. Could HRM support organizational innovation? Innovation and human resource fit: An empirical study. The International Journal of Human Resource Management, v.19, n.7, p. 1208-1221, Jul. 2008. Available from:

<http://www.tandfonline.com/doi/pdf/10.1080/09585190802109952> Access on November $22,2014$.

LOVE, J. H.; ROPER, S. The organisation of innovation: Collaboration, cooperation and multifunctional groups in UK and German manufacturing. Cambridge Journal of Economics, v. 28, n.3, p. 379-395, Apr. 2004. Available from:

<http://cje.oxfordjournals.org/content/28/3/379.short> Access on November 22, 2014.

LUBART, T. Psicologia da criatividade. Porto Alegre: Artmed, 2007. 191 p.

LUNDVALL, B. Políticas de inovação na economia do aprendizado. Revista parcerias Estratégicas, Ministério da Ciência e Tecnologia, Brasilia, v.10, p. 200-218, Mar. 2001. Available from: <http://www.cgee.org.br/parcerias/>. Access on November 22, 2014

MA, H. The Effect Size of Variables Associated With Creativity: A Meta-Analysis. Creativity Research Journal, v.21, n.1, p. 30-42, Feb. 2009. Available from:

$<$ http://personal.stevens.edu/ rchen/creativity/creative\%20person.pdf $>$ Access on November $22,2014$.

MANO, V.; ZAGALO, N. Criatividade: sujeito, processo e produto. In: CONGRESSO LUSOCOM, 8, 2009, Lisboa. Anais... Lisboa, p. 1213-1229, 2009. Available from: <http://conferencias.ulusofona.pt/index.php/lusocom/8lusocom09/paper/viewFile/205/181> . Access on November 22, 2014.

MARKS, A.; HUZZARD, T. Creativity and workplace attractiveness in professional employment. Journal of Human Resource Costing \& Accounting, v.12, n.3, p. 225-238, Jan. 2008. Available from: <http://www.emeraldinsight.com/doi/pdfplus/10.1108/14013380810919868> Access on November 22, 2014.

MARONE, L.; GONZALEZ DEL SOLAR, R. Crítica, creatividad y rigor: vértices de un triángulo culturalmente valioso. Revista Interciencia, Caracas, v.32, n.5, p. 354-357. 2007. Available from:

$<$ http://www.scielo.br/scielo.php?script=sci_nlinks\&ref=000158\&pid=S01045970201200010000700019\&lng=pt/>. Access on November 22, 2014.

MAZZONI, M. O.; STRACHMAN, E. Políticas industriais e de ciência, tecnologia e inovação na Irlanda: ênfase em setores de alta tecnologia e comparação com o Brasil. Revista

REAd | Porto Alegre - Edição 82 - Nº 3 - setembro/dezembro 2015 - p. 549-575 
Sônia Maria Guedes Gondim, Elisabeth Loiola, Franciane Andrade de Morais \& Silvia Cristina da Costa Dutra

Brasileira de Inovação, Campinas, v.11, n.2, p. 277-333. 2012. Available from: <http://www.ige.unicamp.br/ojs/rbi/article/view/742/>. Access on November 22, 2014.

MCMULLAN, W.E.;KENWORTHY, T.P. Creativity and entrepreneurial performance. A general Scientific theory. New York: Springer International Publishing. 2015. 207 p.

MUMFORD, M. D.; HESTER, K. S.; ROBLEDO, I. C. Creativity in organizations: importance and approaches. In MUMFORD, M. D. Handbook of organizational creativity. USA: Eleaser. 2012. p. 3-16.

NAKANO, T. C.; WECHSLER, S. M. Criatividade: Características da produção. Avaliação Psicológica, Porto Alegre, v.6, n.2, p. 261-270, Dec. 2007. Available from: <http://pepsic.bvsalud.org/scielo.php?script=sci_arttext\&pid=S1677-

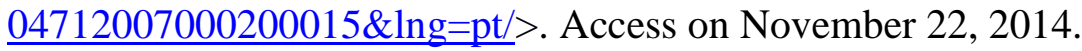

OLDHAM, G.R.; CUMMINGS, A. Employee creativity: Personal and contextual factors at work. Academy of Management Journal, Briarcliff Manor, v.39, n.3, p. 607- 634, Jun. 1996. Available from: http://amj.aom.org/content/39/3/607.full.pdf+html Access on November 22, 2014.

OLIVEIRA, M. A.; NAKANO, T. C. Revisão de pesquisas sobre criatividade e resiliência. Temas em Psicologia, Ribeirão Preto, n.19, n.2, p. 467-479, Dec. 2011. Available from: <http://pepsic.bvsalud.org/scielo.php?script=sci_arttext\&pid=S1413389X2011000200010\&lng=pt\&tlng=pt/> . Access on November 22, 2014.

OSBORN, A. F. Applied Imagination: principles and procedures of creative problem-solving. New York: Scribner, 1963. 417 p.

Oslo Manual: Guidelines for Collectting and Interpreting Innovation Data. Third Edition. OCDE. Paris. 3ed, p.162. 2005. Available from: <http://www.tubitak.gov.tr/tubitak_content_files/BTYPD/kilavuzlar/Oslo_Manual_Third_Edi tion.pdf> Access on November 22, 2014

OSTROWER, F. Criatividade e processos de criação. Ed. 24. Petrópolis: Vozes, 2009. 190 p.

OTTENBACHER, M.; HARRINGTON, R. The innovation development process of Michelin-starred chefs. International Journal of Contemporary Hospitality. v.19, n.6, p. 444460. 2007. Available from: < http://libra.msra.cn/Publication/4933793/the-innovationdevelopment-process-of-michelin-starred-chefs>Access on November 22, 2014.

REAd | Porto Alegre - Edição 82 - Nº 3 - setembro/dezembro 2015 - p. 549-575 


\section{CREATIVITY AND INNOVATION AS DEFINED BY WORKERS}

PARJANEN, S. Experiencing Creativity in the Organization: From Individual Creativity to Collective Creativity. Interdisciplinary Journal of Information, Knowledge and Managemenet, v.7, p. 109-129. 2012. Available from: < http://www.ijikm.org/Volume7/IJIKMv7p109-128Parjanen586.pdf >. Access on November $22,2014$.

PINHEIRO, I. R. Modelo geral da criatividade. Psicologia: Teoria e Pesquisa, Brasília, v.25, n.2, p. 153-160, Apr/Jun. 2009. Available from: < http://www.scielo.br/scielo.php?script=sci_arttext\&pid=S0102$\underline{37722009000200002 \& \operatorname{lng}=e n \& t \operatorname{lng}=\mathrm{pt} 10.1590 / \mathrm{S} 0102-37722009000200002 />}$. Access on November 22, 2014.

RHODES, M. (1961). An analysis of creativity. In: ISAKSEN, S. G. (Ed.), Frontiers of creativity research: Beyond the basics. Buffalo, NY: Bearly, p. 216-222. 1987.

ROAZZI, A.; SOUZA, B. C. Criatividade e desenvolvimento. Publicação interna do Curso de Pós-Graduação em Psicologia, Universidade Federal de Pernambuco, Recife/PE. 1997.

RODRIGUES, A.P.; VELOSO, A. Contribuição da gestão de recursos humanos para a criatividade e inovação organizacional. Revista: Psicologia, Organizações e Trabalho. Florianópolis, v.13, n.3, p. 293-308. Dec. 2013. Available from: < http://pepsic.bvsalud.org/scielo.php?script=sci_arttext\&pid=S1984-66572013000300007 >. Access on November 22, 2014.

SCHUMPETER, J. Capitalismo, socialismo, democracia. Rio de Janeiro: Fundo de Cultura, 1961. $487 \mathrm{p}$.

SCHUMPETER, J. Teoria do desenvolvimento econômico: uma investigação sobre lucros, capital, crédito, juro e o ciclo econômico. São Paulo: Abril Cultural, 1982. 169 p.

SHIPTON, H. et al. HRM as a predictor of innovation. Human Resource Management Journal, v.16, n.1, p. 3-27, Feb. 2006. Available from: < http://onlinelibrary.wiley.com/doi/10.1111/j.1748-8583.2006.00002.x/pdf> Access on November 22, 2014.

STERNBERG, R. J.; LUBART, T. I. The concept of creativity: Prospects and Paradigms. In R.J. Sternberg (ed.) Handbook of Creativity. London:

Cambridge University Press. 1999. p. 3-15. 
Sônia Maria Guedes Gondim, Elisabeth Loiola, Franciane Andrade de Morais \& Silvia Cristina da Costa Dutra

STIERAND, M.; DÖRFLER, V.; MACBRYDE, J. Creativity and Innovation in Haute Cuisine: Towards a Systemic Model. Creativity and Innovation Management, v.23, n.1, p. 1528, Mar. 2014. Available from: < http://onlinelibrary.wiley.com/doi/10.1111/caim.12050/abstract> Access on November 22, 2014.

TORRANCE, E. P. Guiding creative talent. Englewood Cliffs: Prentice, 1962. 206 p.

WECHSLER, S. M. Avaliação multidimensional da criatividade: uma realidade necessária. Psicologia Escolar e Educacional, Campinas, v.2, n.2, p. 89-99. 1998. Available from: < http://www.scielo.br/scielo.php?script=sci_arttext\&pid=s1413-

$85571998000200003 \& \operatorname{lng}=e n \& t \operatorname{lng}=$ t. $10.1590 / \mathrm{s} 1413-85571998000200003 />$. Access on November 22, 2014.

WEST, M. A.; FARR, N. Innovation at work. In: WEST, M. A.; FARR, J. L. (Org.). Innovation and creativity at work: Psychological and organizational strategies. Chichester: John Wiley, 1990. p. 3-13.

WEST, M. A.; SACRAMENTO, C. A. Creativity and Innovation: The Role of Team and Organizational Climate. In: MUMFORD, M. D. Handbook of organizational creativity. USA: Eleaser, 2012. p. 359-386.

WOODMAN, R. W.; SAWYER, J. E.; GRIFFIN, R. W. Toward a theory of organizational creativity. Academy of Management Review, Briarcliff Manor, v.18, n.2, p. 293-321, Apr. 1993. Available from: < http://amr.aom.org/content/18/2/293.abstract> Access on November $22,2014$.

ZANELLA, A. V. et al. Concepções de criatividade: movimentos em um contexto de escolarização formal. Psicologia em Estudo, Maringá, v.8, n.1, p. 143-150, Jan/Jun, 2003. Available from: < http://www.scielo.br/scielo.php?script=sci_arttext\&pid=S141373722003000100017\&lng=en\&tlng=pt. 10.1590/S1413-73722003000100017/>. Access on November 22, 2014.

ZHOU, J.; HOEVER, I. J. Research on workplace creativity: A review and redirection. Annual Review of Organizational Psychology and Organizational Behavior, v.1, n.1, p. 333359, Mar. 2014. Available from: < http://www.annualreviews.org/doi/abs/10.1146/annurevorgpsych-031413-091226>Access on November 22, 2014. 